\title{
Chemical composition, antifungal activity and potential anti-virulence evaluation of the Eugenia uniflora essential oil against Candida spp.
}

\author{
Joycy Francely Sampaio dos Santos ${ }^{\mathrm{a}}$, Janaína Esmeraldo Rocha ${ }^{\mathrm{a}}$, Camila Fonseca Bezerra ${ }^{\mathrm{a}}$, \\ Maria Karollyna do Nascimento Silva ${ }^{a}$, Yedda Maria Lobo Soares de Matos ${ }^{a}$, \\ Thiago Sampaio de Freitas ${ }^{\mathrm{a}}$, Antonia Thassya Lucas dos Santos ${ }^{\mathrm{a}}$, Rafael Pereira da Cruz ${ }^{\mathrm{a}}$, \\ Antonio Júdson Targino Machado ${ }^{a}$, Tigressa Helena Soares Rodrigues ${ }^{\mathrm{b}}$, Edy Sousa de Brito ${ }^{\mathrm{b}}$, \\ Dédora Lima Sales ${ }^{c}$, Waltécio de Oliveira Almeida ${ }^{c}$, José Galberto Martins da Costa ${ }^{\mathrm{d}}$, \\ Henrique Douglas Melo Coutinho ${ }^{a}$, Maria Flaviana Bezerra Morais-Braga ${ }^{\mathrm{a}, *}$
}

${ }^{a}$ Microbiology and Molecular Biology Laboratory - LMBM, Regional University of Cariri - URCA, Crato, CE, Brazil

${ }^{\mathrm{b}}$ Chemical and Natural Products Multiuser Laboratory - LMQPN, Embrapa Agroindústria Tropical, Fortaleza, CE, Brazil

${ }^{\mathrm{c}}$ Zoology Laboratory - LZ, Regional University of Cariri - URCA, Crato, CE, Brazil

d Natural Products Research Laboratory - LPPN, Regional University of Cariri - URCA, Crato, CE, Brazil

A R T I C L E I N F O

\section{Keywords:}

Candida

Eugenia uniflora

Modulation

Micromorphology

\begin{abstract}
A B S T R A C T
The development of fungal resistance to antifungal drugs has been worsening over the years and as a result research on new antifungal agents derived from plants has intensified. Eugenia uniflora L. (pitanga) has been studied for its various biological actions. In this study the chemical composition and antifungal effects of the $E$. uniflora essential oil (EULEO) were investigated against Candida albicans (CA), Candida krusei (CK) and Candida tropicalis (CT) standard strains. The essential oil obtained through hydro-distillation was analyzed by gas chromatography coupled to mass spectrometry (GC-MS). To determine the $\mathrm{IC}_{50}$ of the oil, the cellular viability curve and the inhibitory effects were measured by means of the oil's association with Fluconazole in a broth microdilution assay with spectrophotometric readings. The Minimum Fungicidal Concentration (MFC) was determined by solid medium subculture with the aid of a guide plate while the assays used to verify morphological changes emerging from the action of the fractions were performed in microculture chambers at concentrations based on the microdilution. Two major oil constituents stand out from the chemical analysis: selina-1,3,7(11)trien-8-one (36.37\%) and selina-1,3,7(11)-trien-8-one epoxide (27.32\%). The concentration that reduced microorganismal growth was $\geq 8,192 \mu \mathrm{g} / \mathrm{mL}$ while the $\mathrm{IC}_{50}$ varied, this being between 1892.47 and $12491.80 \mu \mathrm{g} /$ $\mathrm{mL}$ (oil), $10.07-80.78 \mu \mathrm{g} / \mathrm{mL}$ (fluconazole) and $18.53-295.60 \mu \mathrm{g} / \mathrm{mL}$ (fluconazole + oil). The combined activity (fluconazole + oil) resulted in indifference and antagonism. A MFC of the oil in association with fluconazole was recorded at the concentration of $8,192 \mu \mathrm{g} / \mathrm{mL}$ against CA and CK. The oil caused the inhibition of CA and CT morphological transition. In view of the results obtained, additional research is needed to elucidate the activity of the E. uniflora oil over genetic and biochemical processes regarding its effect on Candida spp. virulence.
\end{abstract}

\section{Introduction}

Fungi from the Candida genus are very common as they are part of the normal human microbiota and can be isolated in the most diverse anatomical sites; in the mouth, for example, around 20 to $50 \%$ of healthy teeth are colonized by Candida spp. These are yeast fungi whose most well-known species, Candida albicans, is usually associated with pathological conditions, however, other species such as $C$. tropicalis, $C$. glabrata and C. krusei, are frequently identified (Zomorodian et al., 2011).

Fungal infections caused by opportunistic pathogens have become increasingly frequent, especially as a result of the relentless use of antimicrobial therapies and an increase in the number of immunocompromised patients. While some Candida species form part of

\footnotetext{
*Corresponding author at: Microbiology and Molecular Biology Laboratory, Biological Sciences Department, Regional Univeristy of Cariri - URCA, Rua Cel. Antônio Luís 1161, Pimenta, 63105-000, Crato, CE, Brazil.

E-mail address: flavianamoraisb@yahoo.com.br (M.F.B. Morais-Braga).
} 
the natural human microbiota, these can also become pathogenic, often in association with virulence factors from the microorganism itself, due to immunological conditions of the individual (Chaves, Santos \& Colombo, 2012). Among the main virulence factors associated with the Candida genus, are: epithelial cell adhesion; hydrolytic enzyme secretions such as proteases, phospholipases and hemolysins; biofilm formation; phagocytic cell evasion and transitioning between yeast and hyphal states (Chaves et al., 2013).

The choice of initial antimycotic agent for the treatment of a suspected invasive Candida infection is also difficult. The development of resistance to antifungal agents used in Candida treatment is a situation which has been worsening. Prophylaxis with fluconazole in the last two decades is suggested to have led to an increase in non-albicans species prevalence with a reduced susceptibility to this drug (Perfect, 2004).

In this sense, by utilizing the rich Brazilian flora, research for new antifungal agents derived from plant extracts and essential oils has intensified due to the relatively small arsenal of drugs available for the treatment of mycoses, mainly due to the problem involving the resistance of strains to these (Eddouzi et al., 2013).

Eugenia uniflora L., popularly known as pitanga, is an arboreous plant from the Myrtaceae family which is widely distributed in Brazil and other South American countries. Several plant phytoconstituents of this plant have been studied, such as flavonoids, mono and triterpenoid compounds, tannins, anthraquinones, cineol and essential oils, the results of which proposed that in addition to presenting antimicrobial activity, the species presents several biological actions, such as antioxidant, antihypertensive and diuretic actions (Amorim, Lima, Hovell, Miranda, \& Rezende, 2009).

The objective of this study was to investigate the chemical composition and in vitro effect of the Eugenia uniflora essential oil, both alone and in combination with fluconazole, on the growth inhibition and drug action potentiation against Candida spp, as well as to verify the inhibition of fungal pleomorphism, a virulence factor of yeasts.

The association of the E. uniflora essential oil at a subinhibitory concentration with fluconazole to verify the modulating effect is unprecedented.

\section{Materials and methods}

\subsection{Collection area}

The plant material was collected from an urban area in the municipality of Crato, south of Ceará, Brazil $\left(317 \mathrm{~m}, 07^{\circ}, 14^{\prime}, 08.4^{\prime \prime}\right.$ South latitude and $39^{\circ}, 24^{\prime}, 57^{\prime \prime}$ West of Greenwich). The collection period included January, February, March and April. The samples were collected between 08:30 and 10:30 in the morning. From the collected material, an exsiccate was prepared which was later identified and deposited in the Caririense Dárdano de Andrade-Lima Herbarium (HCDAL) of the Regional University of Cariri - URCA, registered under the number 13099.

\subsection{Plant material and essential oil preparation}

The study was carried out using young and healthy E. uniflora leaves, locally known as pitanga, without any indication of parasitic contamination which were later washed and cut into small pieces. To obtain the oils, the methodology by Gottlieb (1960) was followed where the leaves were separated and placed in a $5 \mathrm{~L}$ glass flask, this being used to extract $221.7 \mathrm{~kg}$ of foliar mass, followed by the addition of approximately $3 \mathrm{~L}$ of distilled water, which was heated for $2 \mathrm{~h}$ in a Clevenger-type equipment. The water/oil mixture obtained was separated, treated with anhydrous sodium sulfate and subsequently filtered. The Eugenia uniflora Leaf Essential Oil (EULEO) obtained by distillation was kept under refrigeration and protected from light until the time of microbiological assays.

\subsection{Gas chromatography coupled to mass spectrometry (GC-MS) - determination of volatile essential oils}

GC-MS analysis was performed on an Agilent instrument, model GC7890B/MSD-5977A (quadrupole), with a $70 \mathrm{eV}$ electron impact, HP5MS methylpolysiloxane column $(30 \mathrm{~m} \times 0.25 \mathrm{~mm} \times 0.25 \mu \mathrm{m}$, Agilent), helium carrier gas with a $1.00 \mathrm{~mL} \mathrm{~min}^{-1}$ ( $8.8 \mathrm{psi}$ ) flow rate and $36.8 \mathrm{~cm} \mathrm{~s}^{-1}$ constant linear velocity, $250{ }^{\circ} \mathrm{C}$ injector temperature, $150{ }^{\circ} \mathrm{C}$ detector temperature, $280^{\circ} \mathrm{C}$ transfer line temperature. Chromatographic oven programming included: $70^{\circ} \mathrm{C}$ initial temperature with a $4^{\circ} \mathrm{C} \mathrm{min}{ }^{-1}$ heating ramp up to $180^{\circ} \mathrm{C}$ and an additional $10^{\circ} \mathrm{C} / \mathrm{min}$ up to $250^{\circ} \mathrm{C}$ at the end of the run $(34.5 \mathrm{~min})$. Compound identification was performed by analyzing the fragmentation patterns exhibited in the mass spectra with those present in the database provided by the equipment (NIST version 2.0 of 2012-243893 compounds) and literature data.

\subsection{Antifungal assays}

\subsubsection{Strains and culture media}

The strains used were of a standard type and obtained from the Oswaldo Cruz Culture Collection (FIOCRUZ) of the Instituto Nacional de Controle de Qualidade em Saúde (INCQS), namely CA INCQS 40006, CT INCQS 40042 and CK INCQS 40095. The strains were inoculated in Sabouraud Dextrose Agar (SDA, KASVI) and incubated for $24 \mathrm{~h}$ at $37^{\circ} \mathrm{C}$. Subsequently, small aliquots of the yeast were transferred to test tubes, each containing $3 \mathrm{~mL}$ of sterile saline $(0.9 \%)$. The inoculum concentration was standardized by comparison to the $0.5 \mathrm{McF}$ arland scale (NCCLS, 2002). Sabouraud Dextrose broth (SDB, HIMEDIA), doubly concentrated, was used in the microdilution assay. In the micromorphological analysis, Potato Dextrose Agar (PDA) depleted with bacteriological agar was used.

\subsubsection{Drugs, reagents and solution preparation}

Dimethyl sulfoxide (DMSO, Merck, Germany) was used to dilute the oil, while the antifungal fluconazole (Capsule; Prati donaduzzi, Brazil) was diluted in water and used as a reference drug. The product solution was prepared by weighing $0.15 \mathrm{~g}$ of the oil and diluting this in $1 \mathrm{~mL}$ of DMSO. To obtain the desired concentration for the test, the oil was further diluted in sterile distilled water $(16,384 \mu \mathrm{g} / \mathrm{mL})$ such that the DMSO concentration did not exert any activity on the tested cells (Stoppa et al., 2009).

\subsection{3. $I C_{50}$ determination and cellular viability curve}

This assay was performed using the broth microdilution method in 96-well plates. Each well was filled with $100 \mu \mathrm{L}$ of CSD containing $10 \%$ fungal inoculum and either $100 \mu \mathrm{L}$ of the natural product $(16,384 \mu \mathrm{g}$ / $\mathrm{mL}$ ) or fluconazole (antifungal reference), in the same concentration to the first well, followed by serial dilution. Concentrations in the wells ranged from 8 to $8192 \mu \mathrm{g} / \mathrm{mL}$. The last well contained no product or drug and served as a normal growth control (Javadpour et al., 1996). Controls were also prepared for the product diluents (with $0.9 \%$ Sodium Chloride solution instead of the inoculum) and the sterile medium. All the tests were performed in quadruplicates. The plates were incubated at $37^{\circ} \mathrm{C}$ for $24 \mathrm{~h}$ and subsequently read on an ELISA spectrophotometer (Thermoplate ${ }^{\circledR}$ ) with a $630 \mathrm{~nm}$ wavelength. The results obtained in the ELISA reading were used to construct the cell viability curve and to determine the $\mathrm{IC}_{50}$ of the E. uniflora essential oil.

\subsubsection{Determination of the minimum fungicide concentration (MFC)}

For this assay the tip of a sterile rod was inserted into each well of the previously tested plate (except for the sterility control). After mixing the medium in each well, the rod was taken to a Petri dish containing SDA with the aid of a guide plate fixed at the bottom of the plate for yeast subculture and cell viability checks. After $24 \mathrm{~h}$ of incubation, the plates were inspected for any formation of Candida 
colonies (Ernst Klepser, Ernst, Messer, \& Pfaller, 1999, with modifications). The concentration in which there was no fungal colony growth was considered the essential oil MFC.

\subsubsection{Evaluation of the essential oil's modifying effect over fluconazole} action

Initially, the intrinsic action of the oil and fluconazole on yeast growth was verified, whereby, in this assay the effect of the combination of the oil and the reference drug was evaluated to determine whether or not the antifungal action was potentiated by the oil. For this, the oil was used at a sub-inhibitory concentration (MFC/16), according to the methodology used by Coutinho, Costa, and Siqueira-Júnior (2008) with minor modifications. If the oil potentiated the action of the antifungal drug, the verified effect would be considered of a synergistic type, if the effect hindered the performance of the drug, an antagonistic effect would be verified. The plates were filled with $100 \mu \mathrm{L}$ of medium + inoculum + oil followed by microdilution with $100 \mu \mathrm{L}$ fluconazole at the concentration of $16,384 \mu \mathrm{g} / \mathrm{mL}$. The mixture was added to the first well of each column to undergo serial dilutions at concentrations ranging from 8192 to $8 \mu \mathrm{g} / \mathrm{mL}$. The last well was intended as a fungal growth control. Dilution controls for the essential oil (where saline substituted the inoculum) and medium sterility controls were performed. The $\mathrm{IC}_{50}$ of fluconazole was also determined for comparative purposes while a dilution control was also required. The plates were incubated at $37^{\circ} \mathrm{C}$ for $24 \mathrm{~h}$. The reading was performed on an ELISA spectrophotometric apparatus (Thermoplate ${ }^{\circledR}$ ).

\subsubsection{Effect of natural products on fungal morphology}

To determine if the natural product caused any changes in fungal morphology through the inhibition of hyphal development, yeast microculture chambers were prepared. Three milliliters of PDA medium depleted by dilution were added to the chambers containing the following essential oil concentrations: Superior Concentration Assayed SCA $(8192 \mu \mathrm{g} / \mathrm{mL}), \mathrm{SCA} / 4$ and SCA $/ 16$. Subculture aliquots were removed from the Petri dishes to make two parallel streaks on the solid medium (PDA) which were then covered with a sterile cover slip. The chambers were placed in an incubator for $24 \mathrm{~h}\left(37^{\circ} \mathrm{C}\right)$, inspected and the results recorded using an optical light microscope (AXIO IMAGER M2-3525001980-ZEISS-Germany) using a $40 \times$ objective. A control for yeast growth (hyphae stimulated by means of exhaustion) was carried out, as well as a control with the conventional antifungal fluconazole for comparative purposes. The assays were performed according to Sidrin and Rocha (2010) and Mendes (2011), with some modifications.

\subsection{Statistical analysis}

The data obtained were checked for their normal distribution and analyzed using a Two-Way ANOVA $(P<0.05 ; \quad$ "P $<0.1$; $\left.{ }_{* * * * *} P<0.0001\right)$ comparing the values for each concentration of the extract, point by point, with Bonferroni's post hoc test. The $\mathrm{IC}_{50}$ values were obtained by non-linear regression analysis with interpolation of the standard curve unknowns obtained from fungal growth assays as a function of the extract concentration and expressed in $\mu \mathrm{g} / \mathrm{mL}$.

For statistical analysis, the software GraphPad Prism, v. 5.0 was used.

\section{Results and discussion}

\subsection{Chemical analysis}

Table 1 shows the composition of the essential oil evaluated, determined by gas chromatography (GC/MS). In this study, we identified 09 compounds, representing $87.71 \%$ of the total composition. Of the components identified, two stand out: selina-1,3,7(11)-trien-8-one (36.37\%) and selina-1,3,7(11)-trien-8-one epoxide (27.32\%). The chemical composition identified partially corroborates with other studies
Table 1

Chemical composition of the Eugenia uniflora essential oil.

\begin{tabular}{lccl}
\hline Compounds & KI calc & KI lit & Relative area \% \\
\hline B-Elemene & 1395 & 1390 & 3.18 \\
Caryophyllene & 1424 & 1419 & 3.16 \\
D-Germacrene & 1485 & 1481 & 2.12 \\
Bicyclogermacrene & 1499 & 1500 & 4.76 \\
$\alpha$-Bulnesene & 1508 & 1509 & 1.34 \\
Germacrene B & 1563 & 1561 & 7.95 \\
Selina-1,3,7(11)-trien-8-one & 1642 & 1634 & 36.37 \\
Germacrone & 1699 & 1693 & 1.51 \\
selina-1,3,7(11)-trien-8-one epoxide & 1755 & 1748 & 27.32 \\
\hline
\end{tabular}

Relative area: compound percentages were obtained electronically from the GCMS percent area data. KI calc (Kovats Index calculated) was calculated from the GC-MS chromatograms, KI lit (Kovats Index literature) calculated using Adams data.

that describe the chemical composition of the E. uniflora essential oil (Weyerstahl, Marschall-Weyerstahl, Christiansen, Oguntimein, \& Adeoye, 1988; Kanazawa \& Greene, 2000; Amorim, Lima, Hovell, Miranda, \& Rezende, 2009; Costa et al., 2010; Oliveira, Lopes, Cabral, \& Eberlin, 2006; Victoria et al., 2012).

The existence of germacrene and selina-1,3,7-trien-8-one components have been reported as the cause of the E. uniflora essential oil antifungal action (Costa et al., 2010). In the study by Victoria et al. (2012) on the E. uniflora essential oil antifungal activity against Candida spp. and its chemical composition, the study presented germacrene and seline-1,3,7-(11)-trien-8-one oxide as the oil's main constituents, constituents also found in our work.

\subsection{Antifungal activity}

In the assays evaluating the cellular viability of $C$. albicans when exposed to the Eugenia uniflora essential oil, the natural product was only able to reduce the fungal cell numbers at high concentrations, higher than $4096 \mu \mathrm{g} / \mathrm{mL}$. The Table 2 shows $\mathrm{IC}_{50}$ values the evaluated product. This result contradicts the study by Victoria et al. (2012) where their results using the same fungus and essential oil were $208.3 \pm 72.1 \mu \mathrm{g} / \mathrm{mL}$. It is noteworthy that in the present study, for greater result reliability, the assay results relied on the sensitivity of the ELISA spectrophotometric reading method.

In another study with the same species, however using the leaf hydroalcoholic extract, an effective concentration of $500 \mu \mathrm{g} / \mathrm{mL}$ was obtained for the cellular viability evaluation (Auricchio, Bugno, Barros, \& Bacchi, 2007). The results obtained from the combination of the essential oil with fluconazole showed a similar behavior to the isolated use of fluconazole, which can be observed by the decay of the curve in the graph. Costa et al. (2015) also evaluated the interaction of this species with the antifungal fluconazole and the hydroalcoholic extract where they verified a synergistic effect demonstrated through the FIC index (Fractional Inhibitory Concentration). In this same study, Minimum Inhibitory Concentration (MIC) results of $125 \mu \mathrm{g} / \mathrm{mL}$ for $C$. albicans and $31.2 \mu \mathrm{g} / \mathrm{mL}$ for $C$. tropicalis were obtained.

Table 2

$\mathrm{IC}_{50}(\mu \mathrm{g} / \mathrm{mL})$ of the Eugenia uniflora Essential Oil (EOLEU) against species from the Candida genus.

\begin{tabular}{|c|c|c|c|}
\hline \multirow[t]{2}{*}{ Products Tested } & \multicolumn{3}{|l|}{ Strains } \\
\hline & CA INCQS 40006 & CT INCQS 40042 & CK INCQS 40095 \\
\hline Fluconazole (FCZ) & 10.07 & 30.05 & 80.78 \\
\hline EOLEU & 1892.47 & 4511.82 & 12491.80 \\
\hline EOLEU + FCZ & 18.53 & 24.20 & 295.60 \\
\hline
\end{tabular}

CA: Candida albicans; CT: Candida tropicalis; CK: Candida krusei; INCQS: Instituto Nacional de Controle de Qualidade em Saúde. 
CA INCQS 40006

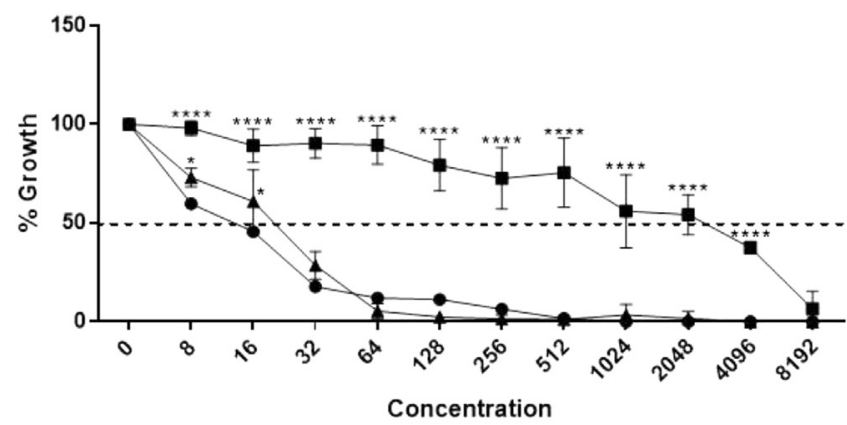

CT INCQS 40042

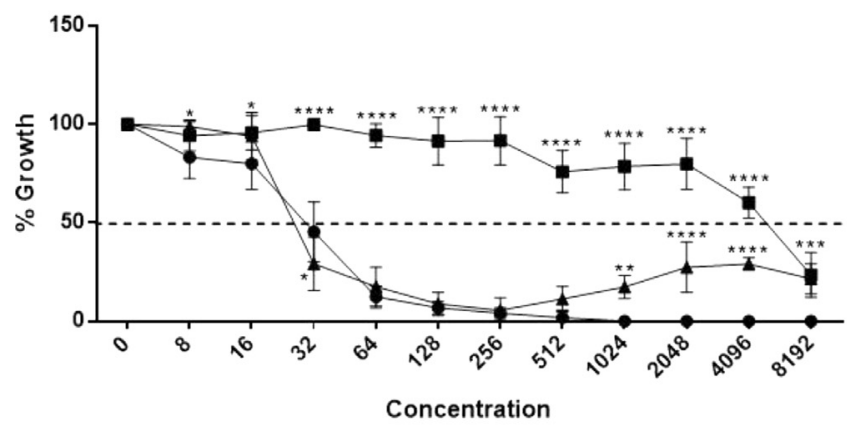

CK INCQS 40095

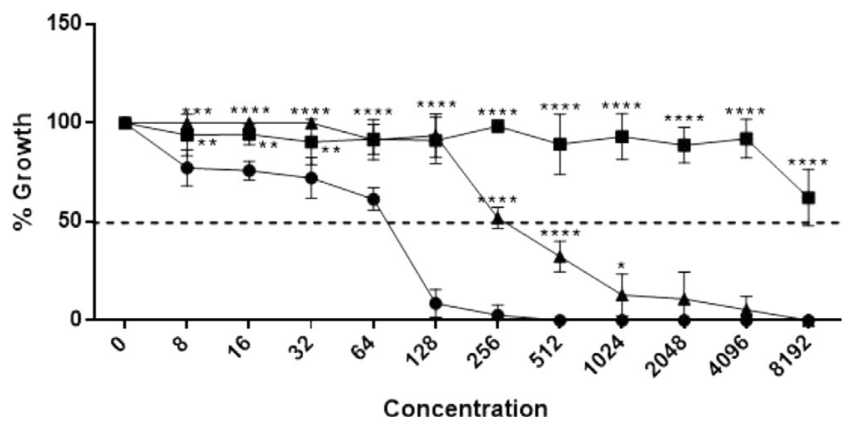

A

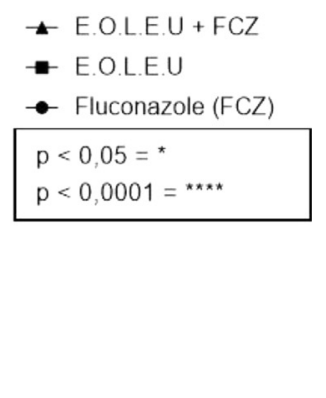

B

$\star$ E.O.L.E.U + FCZ

- e.ole.u

- Fluconazole (FCZ)

$p<0,05=$ *

$p<0,0001={ }^{\star \star \star \star \star}$
C

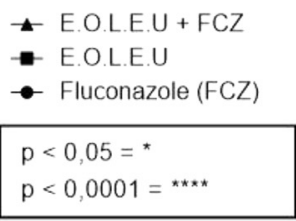

\ E.O.L.E.U + FCZ

- E.O.L.E.U

- Fluconazole (FCZ)

$p<0,0001=^{\star \star \star *}$

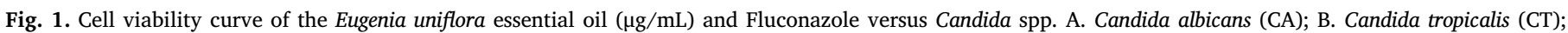
Candida krusei (CK); Eugenia uniflora Leaf Essential Oil (E.O.L.E.U) and fluconazole (FCZ).

The results against C. tropicalis (Fig. 1B) were similar to those obtained with $C$. albicans where the essential oil under study also showed inhibition only at high concentrations, achieving a $50 \%$ reduction in fungal growth only at the $4,096 \mu \mathrm{g} / \mathrm{mL}$ concentration. The decay of the curve was similar for fluconazole as well as for its association with the essential oil, only distancing themselves at $2,048 \mu \mathrm{g} / \mathrm{mL}$ where fluconazole showed a more significant effect.

In the study by Castro and Lima (2011), the E. uniflora essential oil antifungal potential against five $C$. albicans and six $C$. tropicalis strains was also evaluated. The results showed a weak antifungal action as the formation of inhibition halos was observed for only one C. albicans strain using the disc diffusion method, results which corroborates with the data obtained in this work. Santos et al. (2013) evaluated the antifungal and modulatory activity of the $E$. uniflora ethanolic extract against C. tropicalis observing a MIC of $1,024 \mu \mathrm{g} / \mathrm{mL}$, which is also a clinically irrelevant result. However, in the same study, when the natural product was combined with the antifungal metronidazole, a decrease in the MIC of this drug was observed, a result which differs from the present study since the association of the essential oil with fluconazole did not present statistically significant data.

In the experiments against $C$. krusei (Fig. 1C), the essential oil presented high inhibition values, demonstrating that approximately $50 \%$ fungal growth reduction was observed only at $8,192 \mu \mathrm{g} / \mathrm{mL}$ concentrations. The use of fluconazole alone demonstrated a considerable effect at the $128 \mu \mathrm{g} / \mathrm{mL}$ concentration. On the other hand, the modulating effect was similar to that of fluconazole at a concentration of $512 \mu \mathrm{g} / \mathrm{mL}$. Thus, the use of the Eugenia uniflora essential oil in combination with the commercial antifungal fluconazole, requires a higher concentration of this drug to reach similar values to its use in isolation.

When comparing the literature results to those obtained in this study, the essential oil analyzed in this study did not show promising antifungal activity and resistance modulation effects as demonstrated by other authors. The oil composition may have directly interfered with this species' biological action, in view of the contradictory results obtained. However, such results are important to scientifically support the notion that natural product effects in popular medicine can suffer several changes due to several factors, thus presenting different actions.

In order to verify the effect of the oil on the morphology of yeasts, 

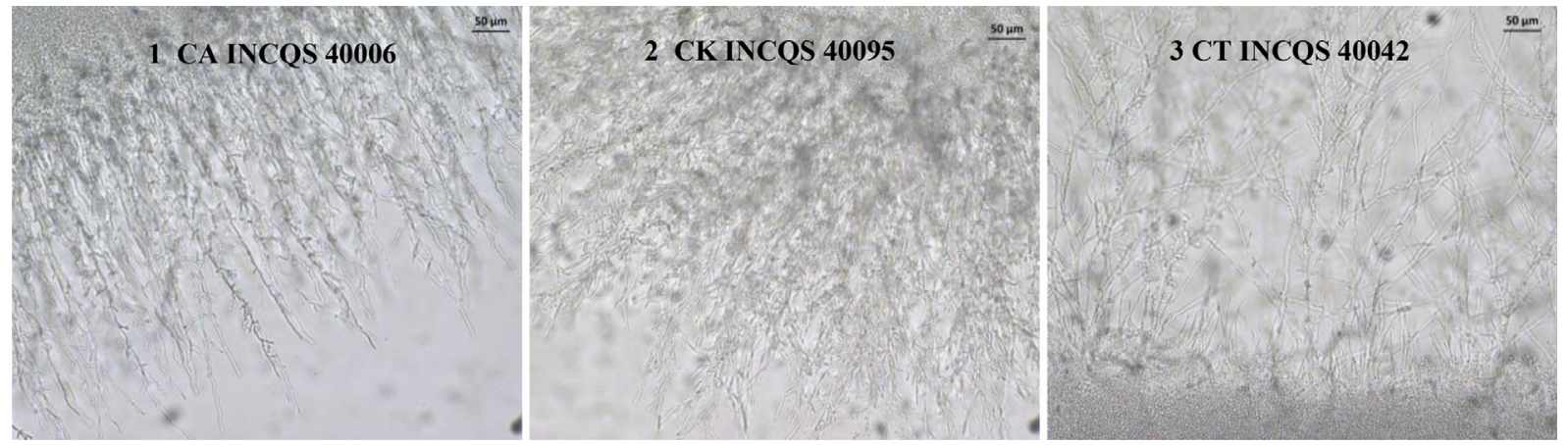

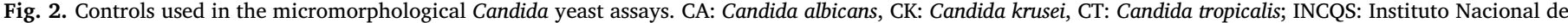
Controle de Qualidade em Saúde. In 1, 2 and 3 - Lineage growth control. Visualisation using a $40 \times$ objective view.

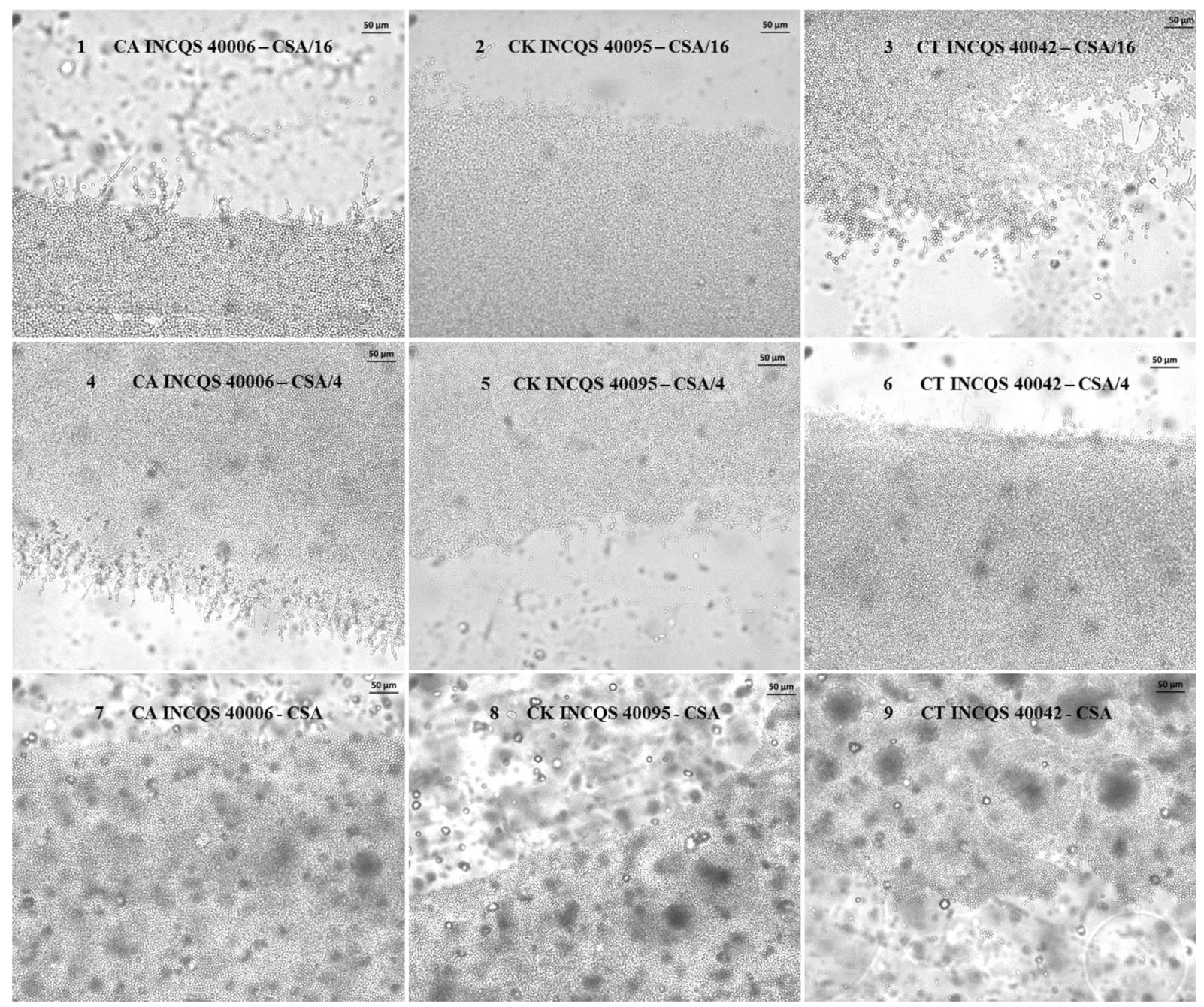

Fig. 3. Controls used in the micromorphological Candida yeast assays. CA: Candida albicans, CK: Candida krusei, CT: Candida tropicalis; INCQS: Instituto Nacional de Controle de Qualidade em Saúde. SCA: Superior Concentration Assayed. In 1, 2 and 3 - Effect of fluconazole at a concentration of 512 $\mu \mathrm{g} / \mathrm{mL}$ (SCA/16); 4, 5 and 6 at the concentration of $2048 \mu \mathrm{g} / \mathrm{mL}$ (SCA/4); 7,8 and 9 at $8192 \mu \mathrm{g} / \mathrm{mL}$ (SCA). Visualisation using a $40 \times$ objective view.

fungal stress was provoked using a depleted medium facilitating the formation of hyphae and pseudohyphae that act in the search of nutrients, demonstrating the pleomorphic characteristic of yeasts (Fig. 2). Regarding fluconazole, filamentous structure inhibition occurred effectively at the highest concentration (Fig. 3), whereas when compared to the growth control, inhibition was already observed from lower concentrations.

As for the essential oil effect, it was observed that this inhibited the growth of $C$. albicans filamentous structures at all concentrations. In $C$. tropicalis, this same effect was indicated only at the highest concentration (SCA). The oil, however, was inefficient against C. krusei where no inhibitory action was observed (Fig. 4).

Virulence inhibition of Candida species has already been observed both by the action of extracts from other species belonging to the Myrtaceae family as well as by the action of plant products derived from other families. Morais-Braga et al. $(2016$; 2017) reported in their study that the aqueous and hydroethanolic extracts from Psidium guajava and Psidium brownianum (Myrtaceae) leaves affected the fungal 


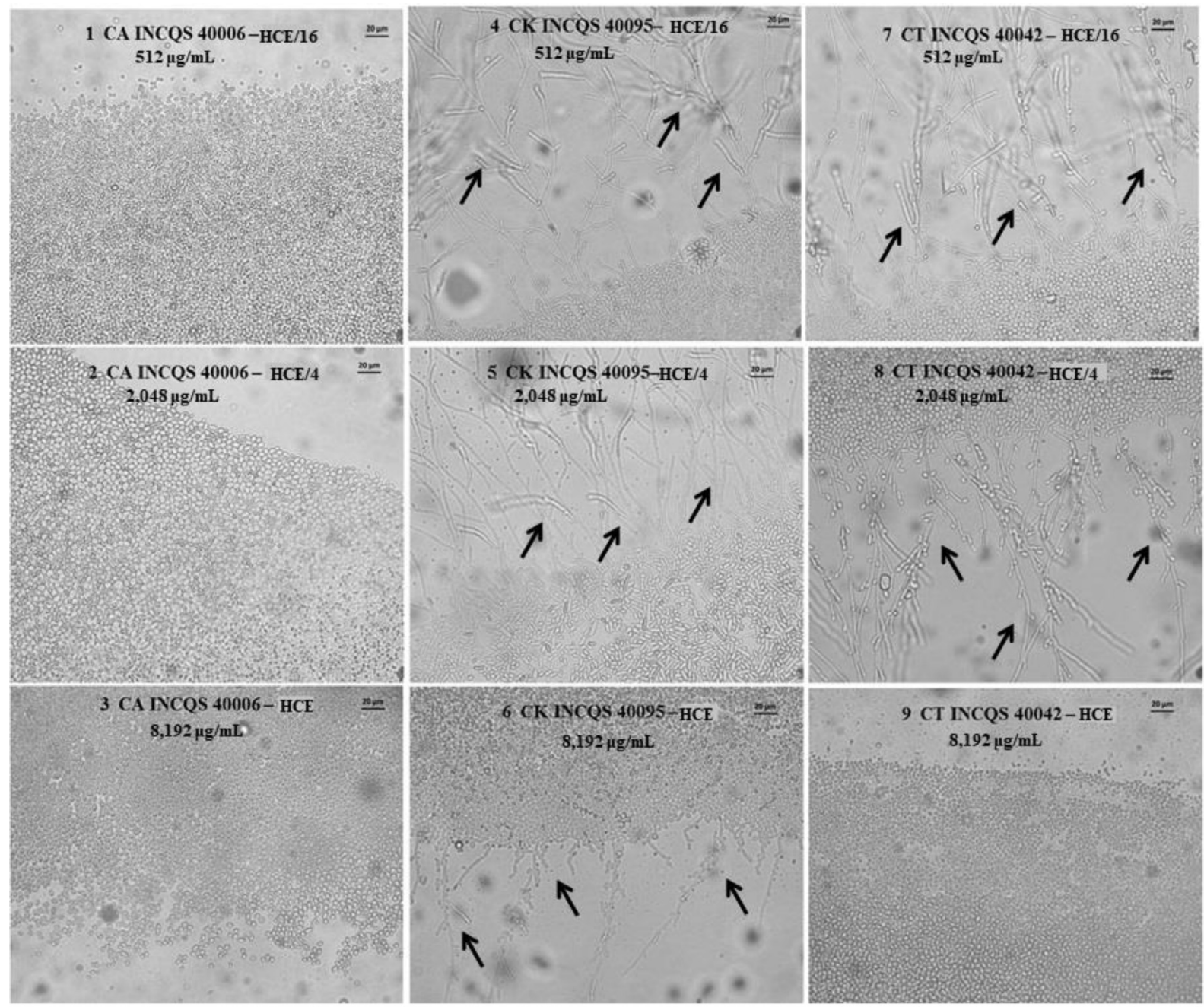

Fig. 4. CA: Candida albicans, CK: Candida krusei, CT: Candida tropicalis; INCQS: National Institute of Quality Control in Health. SCA: Superior Concentration Assayed. Effect of the Eugenia uniflora essential oil on C. albicans, C. krusei and C. tropicalis dimorphism. Concentrations of 512 $\mu$ g/mL (SCA/16); 2048 $\mu \mathrm{g} / \mathrm{mL}$ (SCA/4); $8192 \mu \mathrm{g} / \mathrm{mL}$ (SCA). In 1, 2 and 3 with C. albicans; 4, 5 and 6 with C. krusei and 7, 8 and 9 with C. tropicalis. Visualisation using a $40 \times$ objective view. Arrows indicate the presence of hyphae.

virulence of C. albicans and C. tropicalis at the $16.384 \mu \mathrm{g} / \mathrm{mL}$ concentration. Brito et al. (2015), showed that the C. krusei and C. tropicalis strains cultivated in culture medium in the presence of the Lippia sidoides (Verbenaceae) essential oil did not present pseudohyphae and hyphae at the $256 \mu \mathrm{g} / \mathrm{mL}$ concentration. Meanwhile, Oliveira, Batista, Fernandes, Sales, and Nogueira (2016) showed a reduction in C. albicans hyphae at the $1.25 \mathrm{mg} / \mathrm{mL}$ and $2.5 \mathrm{mg} / \mathrm{mL}$ concentrations, as well as C. albicans $(0.625 \mathrm{mg} / \mathrm{mL}$ and $2.5 \mathrm{mg} / \mathrm{mL})$ and $C$. parapsilosis $(1.25 \mathrm{mg} / \mathrm{mL}$ and $2.5 \mathrm{mg} / \mathrm{mL})$ treated with the Ocimum gratissimum (Lamiaceae) essential oil.

In the case of $C$. albicans, the hyphae and pseudohyphae inhibitory action can be observed from the lowest $(512 \mu \mathrm{g} / \mathrm{mL})$ to the highest concentration $(8.192 \mu \mathrm{g} / \mathrm{mL})$. This effect may be directly related to the inhibition of fungal cell growth and to the formation of inhibition halos. This may suggest dose-dependency, justifying the action observed in the micromorphology assays.

O efeito de inibição de hifas visto em todas as concentrações em $C$. albicans e na maior concentração em $C$. tropicalis pelo óleo essencial de E. uniflora, deve estar relacionado a sua composição química. Visto que os compostos encontrados em maior quantidade foram a selina1,3,7(11)-trien-8-one e selina-1,3,7(11)-trien-8-one epoxide, respectivamente. A ação inibitória de crescimento pode estar associada a estes compostos ou com a combinação de outros também identificados, mas em menor quantidade. Mais estudos são necessários visando compreender a ação isolada destas substâncias quando se tratando da micromorfologia, se as mesmas são responsáveis pela inibição de hifas e pseudo-hifas isoladamente ou em associação com os outros compostos, pois na literatura esta informação ainda não foi elucidada.

The hyphael inhibitory effect seen by the $E$. uniflora essential oil at all concentrations against $C$. albicans, and at the highest concentration against $C$. tropicalis, could be related to its chemical composition since the compounds found in greatest quantities were selena-1,3,7(11)-trien8-one and selina-1,3,7(11)-trien-8-one epoxide, respectively. The inhibitory growth action may be associated with these compounds or with the combination of other compounds also identified, however in lower quantities. Further studies are needed to understand the isolated action of these substances with regards to micromorphology and to determine if they are responsible for the inhibition of hyphae and pseudohyphae alone or in association with the other compounds as this information has not been previously elucidated in the literature.

\section{Conclusion}

High concentrations of the $E$. uniflora essential oil were required to obtain an antifungal effect. The combination of the oil and fluconazole did not show synergism, however good results were obtained especially in relation to inhibition of the $C$. albicans and $C$. tropicalis morphological transition process, which in human infections can cause tissue invasion. 
Further research is needed to understand the oil activity over the fungi biochemical and genetic processes related to fungal virulence inhibition.

The E. uniflora essential oil had in this study a reduced antifungal potential in the experiments performed and it presented in its composition the predominance of mono- and sesquiterpenes, constituents possessing antifungal effect already evidenced in the literature which may have contributed to the fungistatic effect observed in the assays. Inhibition of Candida spp. colonies using the oil was evidenced in the MFC assay revealing a fungistatic action, however, this had an antagonistic effect when it was associated with Fluconazole and it is thus not advisable to use them in conjunction due to the reduced the performance of the drug. However, this association regressed and affected morphological transition through the emission of filamentous structures, an important fungal virulence factor, especially against $C$. albicans and C. tropicalis. These results show that this compound has active antifungal constituents, however, further studies are needed to prove its effectiveness and safety.

Further studies using animal models are required to verify the in vivo efficacy of the oil.

\section{Declaration of interest}

The authors declare that there are no conflicts of interest regarding the publication of this paper.

\section{References}

Amorim, A. C., Lima, C. K., Hovell, A. M., Miranda, A. L., \& Rezende, C. M. (2009). Antinociceptive and hypothermic evaluation of the leaf essential oil and isolated terpenoids from Eugenia uniflora L. (Brazilian Pitanga). Phytomedicine, 16(10), 923-928.

Auricchio, M. T., Bugno, A., Barros, S. B. M., \& Bacchi, E. M. (2007). Atividades antimicrobiana e antioxidante e toxicidade de Eugenia uniflora. Latin American Journal of Pharmacy, 26(1), 76.

Brito, D. I. V., Morais-Braga, M. F. B., Cunha, F. A. B., Albuquerque, R. S., Carneiro, J. N. P., Lima, M. S. F., ... Coutinho, H. D. M. (2015). Análise fitoquímica e atividade antifúngica do óleo essencial de folhas de Lippia sidoides Cham. e do Timol contra cepas de Candida spp. Revista Brasileira de Plantas Medicinais, 17(4), 836-844.

Castro, R. D., \& Lima, E. O. (2011). Screening da Atividade Antifúngica de Óleos Essenciais sobre Cepas de Candida. Pesquisa Brasileira em Odontopediatria e Clínica Integrada, 341-345.

Chaves, G. M., Diniz, M. G., da Silva-Rocha, W. P., De Souza, L. B., Gondim, L. A. Ferreira, M. A., ... Milan, E. P. (2013). Species distribution and virulence factors of Candida spp. isolated from the oral cavity of kidney transplant recipients in Brazil. Mycopathologia, 175(3-4), 255-263.

Chaves, G. M., Santos, F. P., \& Colombo, A. L. (2012). The persistence of multifocal colonization by a single $\mathrm{ABC}$ genotype of Candida albicans may predict the transition from commensalism to infection. Memorias do Instituto Oswaldo Cruz, 107(2), 198-204.

Costa, D. P., Alves Filho, E. G., Silva, L. M. A., Santos, S. C., Passos, X. S., Silva, M. R. R., ... Ferri, P. H. (2010). Influence of fruit biotypes on the chemical composition and antifungal activity of the essential oils of Eugenia uniflora leaves. Journal of the Brazilian Chemical Society, 21, 851-858.

Costa, G. M., Endo, E. H., Cortez, D. A. G., Ueda-Nakamura, T., Nakamura, C. V., \& Dias Filho, B. P. (2015). Effect of plant extracts on planktonic growth and biofilm of
Staphylococcus aureus and Candida albicans. International Journal of Current Microbiology and Applied Sciences, 4(6), 908-917.

Coutinho, H. D. M., Costa, J. G. M., Siqueira-Júnior, J. P., \& Lima, O. L. (2008). In vitro anti-staphylococcal activity of Hyptis martiusii Benth against methicillin-resistant Staphylococcus aureus: MRSA strains. Revista Brasileira de Farmacognosia, 18, 670-675.

Eddouzi, J., Parker, J. E., Vale-Silva, L. A., Coste, A., Ischer, F., Kelly, S., ... Sanglard, D. (2013). Molecular mechanisms of drug resistance in clinical Candida species isolated from Tunisian hospitals. Antimicrob Agents Chemother, 57(7), 3182-3193.

Ernst, E. J., Klepser, M. E., Ernst, M. E., Messer, S. A., \& Pfaller, M. A. (1999). In vitro pharmacodynamic properties of MK-0991 determined by time-kill methods. Diagnostic Microbiology and Infectious Disease, 33, 75-80.

Gottlieb, O. R., \& Magalhães, M. T. (1960). Essential oil of the bark and wood of Aniba canelilla. Perfumery and Essential Oil Record, 51(69).

Javadpour, M. M., Juban, M. M., Lo, W. C., Bishop, S. M., Alberty, J. B., Cowell, S. M., .. McLaughlin, M. L. (1996). De novo antimicrobial peptides with low mammalian cell toxicity. Journal of Medicinal Chemistry, 39, 3107-3113.

Kanazawa, A., Patin, A., \& Greene, A. E. (2000). Efficient, highly enantioselective synthesis of selina-1, 3, 7 (11)-trien-8-one, a major component of the essential oil of Eugenia uniflora. Journal of natural products, 63(9), 1292-1294.

Mendes, J. M. (2011). Investigação da atividade antifúngica do óleo essencial de Eugenia caryophyllata Thunb. sobre cepas de Candida tropicalis. Dissertação de Mestrado em Produtos Naturais e Sintéticos Bioativos. João Pessoa - PB: Universidade Federal da Paraíba - UFPB.

Morais-Braga, M. F. B., Carneiro, J. N. P., Machado, A. J. T., Sales, D. L., Brito, D. I. V., Albuquerque, R. S., ... Coutinho, H. D. M. (2016). High-performance liquid chromatography-diodic array detector, fungistatic, and anti-morphogenical analysis of extracts from Psidium brownianum Mart. ex DC. against yeasts of the genus Candida. International Journal of Food Properties, 19(8), 1837-1851.

Morais-Braga, M. F. B., Carneiro, J. N. P., Machado, A. J. T., Sales, D. L., Dos Santos, A. T., Boligon, A. A., ... Coutinho, H. D. (2017). Phenolic composition and medicinal usage of Psidium guajava L.: Antifungal activity or inhibition of virulence? Saudi Journal of Biological Science, 24(2), 302-313.

NCCLS Norma M27-A2. Método de Referência para Testes de Diluição em Caldo para Determinação da Sensibilidade à Terapia Antifúngica das leveduras; Norma Aprovada - Segunda Edição. Norma M27-A2 do NCCLS (ISBN 1-56238-469-4). NCCLS, 940 West Valley Road, Suite 1400, Wayne, Pennsylvania 19087-1898 Estados Unidos, 2002 .

Oliveira, A. L., Lopes, R. B., Cabral, F. A., \& Eberlin, M. N. (2006). Volatile compounds from pitanga fruit (Eugenia uniflora L.). Food Chemistry, 99, 1-5.

Oliveira, L. B. S., Batista, A. H. M., Fernandes, F. C., Sales, G. W. P., \& Nogueira, N. A. P. (2016). Atividade antifúngica e possível mecanismo de ação do óleo essencial de folhas de Ocimum gratissimum (Linn.) sobre espécies de Candida. Revista Brasileira de Plantas Medicinais, 18(2), 511-523.

Perfect, J. R. (2004). Antifungal resistance: The clinical front. Oncology, 18(14), 15-22.

Santos, K. K. A., Matias, E. F. F., Tintino, S. R., Souza, C. E. S., Morais-Braga, M. F. B., Guedes, G. M. M., ... Coutinho, H. D. M. (2013). Enhancement of the antifungal activity of antimicrobial drugs by Eugenia uniflora L. Journal of Medicinal Food, 16(7), 669-671.

Sidrin, J. J. C., \& Rocha, M. F. G. (2010). Micologia médica à luz de autores contemporâneos. Rio de Janeiro: Guanabara Koogan388.

Stoppa, M. A., Casemiro, L. A., Vinholis, A. H. C., Cunha, W. R., Silva, M. L. A., Martins, C. H. G., \& Furtado, N. A. J. C. (2009). Estudo comparativo entre as metodologias preconizadas pelo CLSI e pelo EUCAST para avaliação da atividade antifúngica. Química Nova, 32, 498-502.

Victoria, F. N., Lenardão, E. J., Savegnago, L., Perin, G., Jacob, R. G., Alves, D., .. Nascente, P. S. (2012). Essential oil of the leaves of Eugenia uniflora L.: Antioxidant and antimicrobial properties. Food and Chemical Toxicology, 50, 2668-2674.

Weyerstahl, P., Marschall-Weyerstahl, H., Christiansen, C., Oquntimwin, B. O., \& Adeoye, A. O. (1988). Volatile constituents of Eugenia uniflora leaf oil. Planta Medica, 54, $546-549$.

Zomorodian, K., Haghighi, N. N., Rajaee, N., Pakshir, K., Tarazooie, B., Vojdani, M., ... Vosoghi, M. (2011). Assessment of Candida species colonization and denture-related stomatitis in complete denture wearers. Medical Mycology, 49, 208-211. 